\section{The Public Perception of the Print and Electronic Newspapers and Magazines Editions-Case of Serbia}

\author{
Nenad Perić, Milica Vasiljević Blagojević, \\ Nenad Vujić
}

JEL: M12, D83

\section{INTRODUCTION}

The importance of bringing new technologies into the world of print media is great and undeniable. Digital technologies have been a part of daily newspaper world for many decades. People working for newspapers started using computer technologies in the 60s of the last century. Computer technology revolutionized the production of newspapers and print media in general during the last two decades. Today, journalists and photojournalists use computers and computer systems for editing texts, images and news. The World's leading newspapers have their own platforms for the content collection and distribution, thus speeding up the workflow processes while ensuring the quality (Veglis, 2007).

However, although the development of information technologies has been improving and modernizing the job posts and the work flow, the basic media format has remained the same. For a long time, the newspaper organizations were occupied only with the distribution of the print newspapers. As technology for the distribution of journalistic information in various forms has become more easily available with the emergence of the Internet and the World Wide Web, the tendency has been for the media organizations and companies to have at their disposal several channels for the publishing of information, news, advertisements, etc. (Cappo, 2004). In the previous decade the web sites of many newspapers are enhancing their services and are used to expand their readership, both in print and electronic form. It is obvious that media companies have completely altered forms and strategies. Reporters cover events with several possible publishing channels in mind, which was foreseen by Bartlett in 1994 (Bartlett, 1994). The research conducted in 2007 about the use of alternative channels for information distribution of top 10 American daily papers shows that the big companies have been on that road for some time now (Veglis, 2007).

The formula for the innovation diffusion through the social system is well documented and follows a classic S-shape, the shape of a curve of adopting over time. The theory describes five different categories of "adopters" and their approximate percentage in each of the categories: innovators (2.5\%), early adopters (13.5\%), early majority (34\%), late major-
Abstract: Complex research in the field of print and electronic media and relations preference towards them has been non-existent in Serbia, so the paper aims to provide initial guidance in this regard. An instrument (questionnaire) was formulated for the purposes of this study and used for measuring respondents' assessment of strengths and weaknesses of the print or electronic media. The research was conducted at the national level in Serbia, with a large number of respondents (432), using a number of different variables on the Likert scale. Respondents evaluated a total of ten items pertaining to different aspects of the advantages and disadvantages of print and electronic editions. The results can be of great importance to the media and other participants in the advertising industry-advertising agencies and advertisers. The scientific contribution of this paper is shown in the initial data the researchers gained in the fields of the media, marketing and advertising, regarding the perception of the print and electronic newspapers and magazines editions in Serbia.

Key words: newspapers, electronic editions, journalism, information, consumers 
ity (34\%) and laggards (16\%). This classification can be used to present the process by which information technology has become a part of newspaper profession, but also media reality (Rogers, 1995).

Newspaper publishers increasingly distribute their own content as well as propaganda via several distribution channels, but mainly by combining print and WWW. Since the subject of our research is print and electronic editions of newspapers and magazines, we shall investigate them further.

The print is the oldest and most widely spread publication channel. Print channel has its limitations such as the time needed for production - printing of the content. In general, the process starting from planning through leaving the print and distributing is time-consuming and, in many cases, complex (Veglis, 2007).

On the other hand, the main advantage of the Web over the other publishing channels is the long distance distribution of information, with the possibility of continuous updating. Information on the Web need no physical transport which is a desirable quality both from the economic and the environmental point of view (Veglis, 2007), especially in the $21^{\text {st }}$ century. Every article published on Internet could be supplemented by an unlimited number of photos and additional video material. In addition, electronic editions can contain links that directly connect readers to additional sources of information. Further more, electronic editions allow readers to easily and quickly communicate their views and thoughts related to a specific topic or article by using comments, and even to enter into polemics with other readers.

Although the traditional media quickly moved to the net, the majority of them did so without detailed consideration of the content and the economical aspect. Traditional media turned to the Internet as the channel to "save" the consumers and as a way to ensure the survival implementing the strategy the Internet as a business model (Bressers, 2006; Ketterer, Veir, Smethers, Back, 2004; Picard, 2010).

The presence of traditional media on the Internet is mostly based on the content formulated in similar way as the content in traditional media. The most common case found is that the electronic content is, in fact, a substitution for the physical product (Chyi \& Lewis, 2009; Seelig, 2007, 2008). We can reach the conclusion that there is no clear strategy concerning the Internet, not only content-wise, but also financially (Picard 2010). A great number of the research considered traditional motives of the media for the presence on the Internet (Boczkovski, 2004, Chan-Olmsted \& Ha,
2003). The results did not uphold the theory that the competition in traditional media is enormous when talking about the content, nor that the traditional media are to be substituted by electronic editions; instead, the results confirmed that the online version completes the traditional product (Chan-Olmsted \& Ha, 2003. Saksena \& Hollifield, 2002).

The conclusion of the research is that, besides the economical legitimacy of online publishing (decreasing the costs for production and product distribution), the Internet solution intended for wider public stimulates interactivity with the consumers, provides various content and information, changes the way the data is being collected, and gives preference with respect to the competition, positioning itself in front of and/or keeping abreast with the technology (Seelig, 2007).

According to the research of Pew Research Center conduicted during 2016, 62\% of Americans on an average day uses social networks (Reddit, Facebook, Twitter...) in order to inform themselves, and 18\% does it very often (News Use Across Social Media Platforms 2016).

With the growth of the Internet media content in general is much greater than ten or twenty years. The audience has an almost unlimited choice. The result is quick changes of audience from one media content to another and combining different media simultaneously. Schroeder named the behavior of the audience today as "cross-media“ (Schröder, 2011). Therefore, media organizations need to inovate the mode of production and marketing of products to the increasingly fierce competitive conditions and provide enough audience in order to survive.

This image of news consumers' needs and habits had an impact on the traditional industry of print media. The number of regular readers of local and national press, according to Pew Research Centre, has declined for 50\%, and the use of the news "collector", such as Google News, becomes an everyday habit. The usual reading of morning or evening newspapers which marked the previous decades is changing under the influence of new technologies and is becoming a search for the news which in global media space no longer depends on the times of the day, working hours or time zones. Therefore, the question is not whether print media will die, but when (Perić, Karsulja, Radojević, 2011).

Comprehensive research about the preferences and habits of the readers in Serbia regarding the electronic media does not exist, and this paper represents an initiative in that regard. 


\section{marketing}

\section{RESEARCH}

\subsection{Research methodology}

\section{Aim}

Starting from the fact that this type of research has not been done in this area, while bearing in mind that blanket statements are often being made in public about the print and electronic editions of newspapers and magazines, we were motivated to explore this phenomena in more detail. The aim was to determine peoples' evaluation of print and electronic editions and whether or not the print media is slowly but surely dying out.

\section{Hypotheses}

- Older respondents prefer print editions

- Younger respondents prefer electronic editions

- Decrease in finances boosts the preference towards electronic editions

- As the level of education rises so does the preference towards electronic editions

- There is no significant difference in preferences towards print or electronic media when talking about gender distribution

\section{Work methodology}

The research is non-experimental, and based on the procedure used, it is a type of poll research.

\section{Research methods}

- researching by using survey

\section{Research instruments}

A questionnaire about the respondents' positions and opinions on print and electronic media was formulated for the purposes of this research.

\section{Population and sample}

Population means the inhabitants of all regions in Serbia, and the sample was stratified from a random sample and includes 432 respondents, not including $3 \%$ of statistical sampling error and non-response rate.

\section{Research flow}

The research was performed in January and February 2017, in face to face contact with the respondents.

\section{Statistical processing}

Descriptive statistical measures were used in statistical processing: frequencies and percentages, average values, deviation measures and statistical significance measures - parametric and non-parametric, Chisquare test was used.

\subsection{Preliminary analysis - general data}

The research included the total of 432 respondents, of which 267 respondents male and 165 female.

\section{CHART 1 Distribution of respondents based}

on their professional qualifications

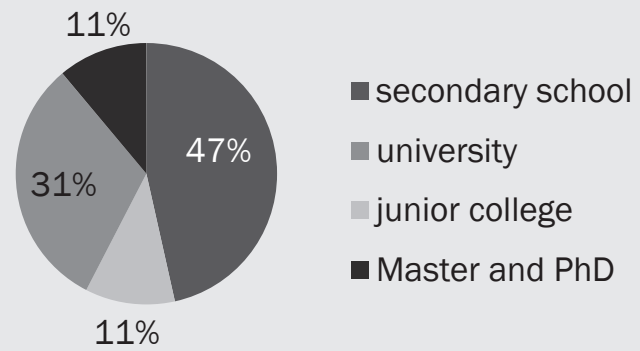

SOURCE: Authors' research

Based on their professional qualifications, the respondents were divided into the following four categories: those who finished secondary school (46.5\%), those who completed junior college (11.1\%), those with university degrees (31.3\%) and those with Master or PhD degrees (11.1\%).

As for the age of the respondents, there were four categories as shown in Chart 2.

\section{CHART 2 Distribution of respondents}

based on their age

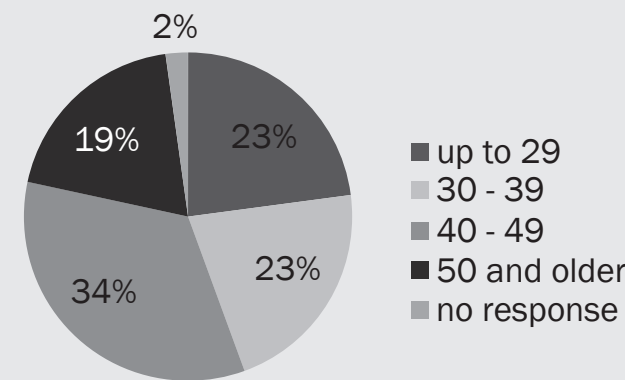

SOURCE: Authors' research 
CHART 3 Distribution of respondents

based on their income

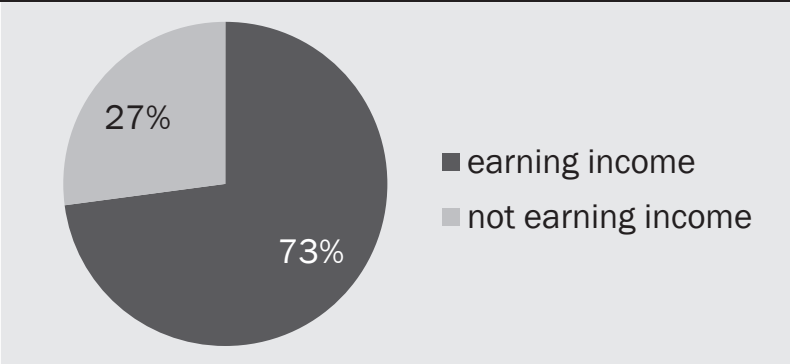

SOURCE: Authors' research

Based on their income, the respondents were divided into two categories: those who earn income $(72.9 \%)$ and those who do not $(27.1 \%)$.

\section{CHART 4 Distribution of respondents based \\ on the length of their length of service}

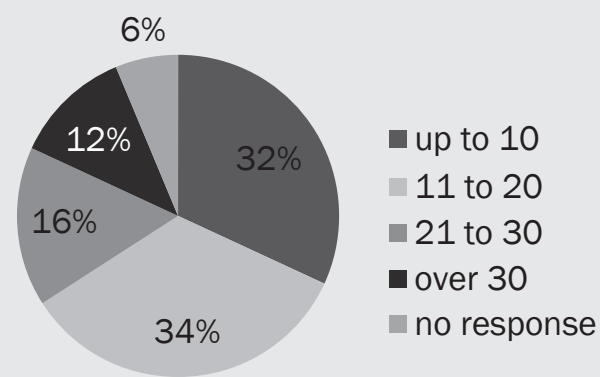

SouRcE: Authors' research

Based on the length of their service, the respondents were divided into following categories: up to 10 years $(31.9 \%)$, from 11 to 20 (34.0\%), from 21 to 30 (16.0\%) and over 30 years of service (11.8\%). $6.3 \%$ of respondents gave no response to this question.

As for the personal monthly income, the respondents were divided into 4 categories as shown in Chart 5 .

\section{CHART 5 Distribution of respondents based} on their personal monthly income

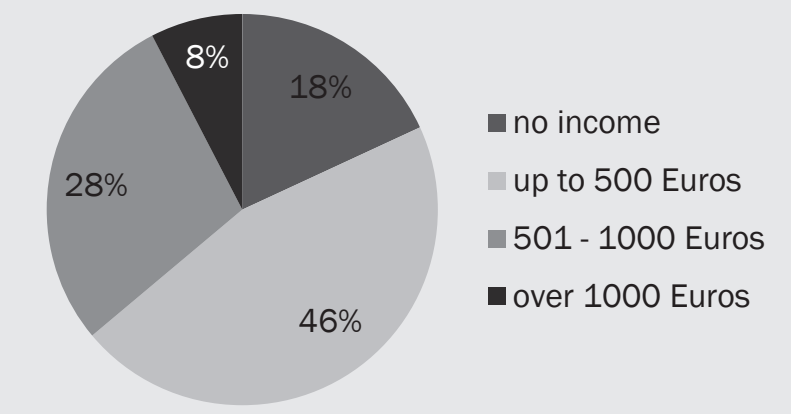

SOURCE: Authors' research
Based on the monthly household income, the respondents were divided into following categories: no household income $(8.2 \%)$, income below 500 Euros (18.7\%), from 501 to 1,000 Euros (41.0\%), from 1,001 to $1,500(18.7 \%)$ and over 1,500 Euros (13.4\%).

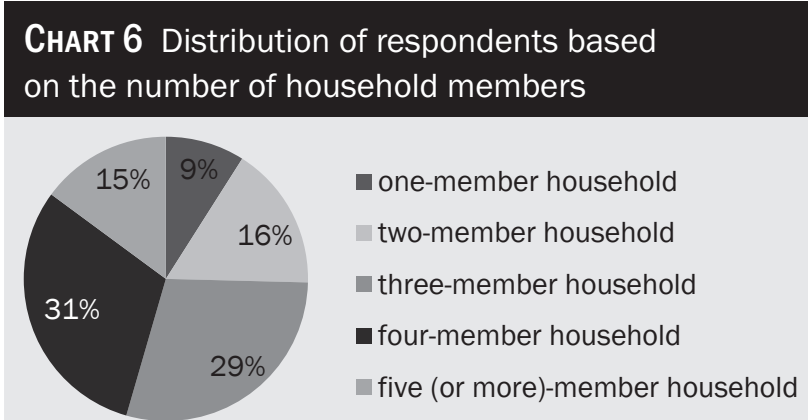

SOURCE: Authors' research

The number of household members is given as shown in Chart 6 through the following categories: one-member household (9.0\%), two-members household (16.4\%), three-members household (29.1\%), four-members household (30.6\%) and five (or more)-members household (14.9\%).

The respondents were divided into following 4 categories as shown in Chart 7 based on how many family members earn income.

ChART 7 Distribution of respondents based

on how many family members earn income

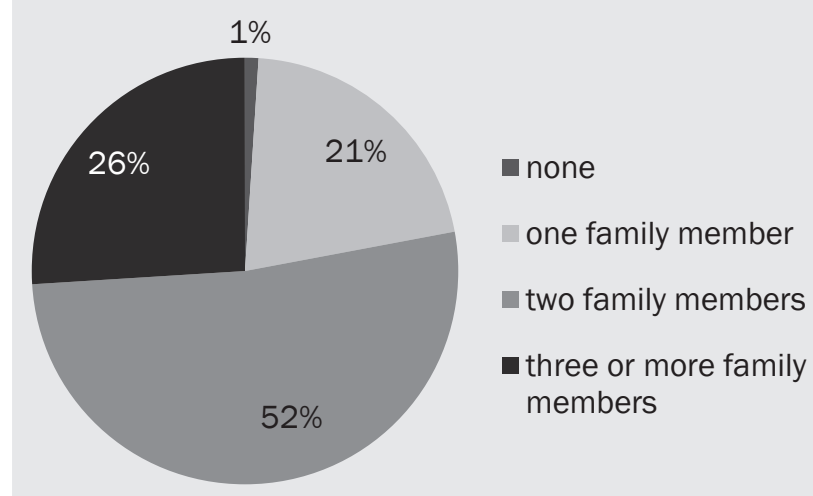

SOURCE: Authors' research

\subsection{Research results}

The respondents evaluated the level of agreeing with the statements made about the print and electronic editions of newspapers and magazines using a five degree Likert-type scale. In the five degree scale 1 meant total disagreement and 5 meant complete agreement with the statement. They had to evaluate ten state- 
ments in total concerning the different aspects of advantages and disadvantages of the print and electronic editions. By using Varimax rotation to analyze main components, two factors were singled out which, when combined, explain $66.67 \%$ of the total variants. The first factor is called "the advantages of print editions" and explains $38.08 \%$ of the variant. It is saturated with statements referring to the various types of advantages of the print editions, such as good layout, more natural for reading and general affinity towards print editions in general. The second factor is called "the advantages of electronic editions" and explains $28.59 \%$. This factor is saturated with statements referring to the advantages of electronic editions, such as: financial advantages, accessibility and higher level of addressing the respondents' needs. This factorial structure shows us that it is possible to explain a significant part of respondents' answers' variants through these two factors when addressing the positions towards the electronic and print editions of newspapers and magazines. Moreover, it informs us about the two groups of answers, that is, the two groups of positions on different editions. On the one hand we have the positions that support print editions, and on the other hand, the ones that support electronic ones.

\subsection{Demographic variables and the comparison with the print and electronic editions of newspapers and magazines}

Single-factor analyses of variance were used to compare the differences in agreeing, with two factors singled out by analyzing main components, depending on the number of household members. Results of the said analyses have shown that significant differences exist between the five variables of the household members number, only in case of the factor called advantages of print editions, $\mathrm{F}(4,421)=4.93, \mathrm{p}<.01$. Also, the results have shown that when the number of household members increases, the level of agreement with the items forming the advantages of print editions factor decreases. Such a result means that the level of agreement with the preference of print editions factor varies depending on the household members' number variable category to which the respondent belongs. The preference towards the print editions reduced with the increase of the number of household members.

Additionally, single-factor analyses were used to compare the differences in agreeing with two provided factors, depending on the four variable categories for the household members with income, and no significant differences were found in any of the two factors. This means that the level of agreement with the singled out factors does not change depending on which of the four variable categories the respondent belongs to.

As for the amount of personal income, single-factor analyses of variance have shown that, depending on which of the four categories of this variable the respondent belongs to, there are more pronounced differences in matching with the statements forming the advantage of electronic editions factors, $\mathrm{F}(3$, $422)=11.50, p<.01$. Obtained results indicate that the level of agreement of the respondents with the advantages of the electronic editions differs significantly depending on which of the four incomes level categories the respondent belongs to. With the increase of the income, the preference towards electronic editions increased.

T-tests for two separate factors on separate samples were used for comparison of differences in agreeing with the statements, depending on the respondent's gender. Significant differences were shown to exist in the advantages of print editions factor $t(424)=-4.50$, $\mathrm{p}<.01$. Additionally, it was shown that women agree more with the statements regarding print editions, while men prefer electronic editions more.

Single-factor analyses of variance were used to compare levels of agreeing with the two singled out factors, depending on the five categories of the household income level. The results shown that significant differences exists for both factors: advantages of print editions $\mathrm{F}(4,421)=4.00, \mathrm{p}<.01$ and advantages of electronic editions, $\mathrm{F}(4,421)=13.36, \mathrm{p}<.01$. As for the advantages of print editions, agreement with them reduces as the personal income increases. On the other hand, as personal income increases, the level of agreement with the advantage of electronic editions factor increases.

T-test of separate samples was used to compare the differences between the employed and unemployed respondents, and significant differences were discovered with regards to the advantage of print editions factor, $t(424)=-2.63, \mathrm{p}<.01$. At the same time, the respondents without any income are more prone to agreeing with the statements on the advantages of the print editions. Such results indicate that the level of agreement with the advantages of the print editions differs depending on whether the respondents are employed or not. This finding can be also construed by the fact that people without income are also unemployed and have more spare time in which they 
prefer more to read print editions of newspapers and magazines.

Single-factor analyses of variance were used for comparison of differences between the singled out factors, depending on the four categories of the respondents' length of service. Significant differences have been found in both factors: advantages of print editions, $\mathrm{F}(3,395)=7.47, \mathrm{p}<.01$ and advantages of electronic editions, $\mathrm{F}(3,395)=5.83, \mathrm{p}<.01$. Also, results have shown that with the increase of the length of service, agreement to the advantages of print editions also increases, while agreeing with the advantages of the electronic editions decreases. This means that the level of agreement with both of the singled out factors differs significantly depending on which length of service variable category the respondents belong to.

Single-factor analyses of variance were used for comparison of differences between the singled out factors, depending on the four categories of the respondents' professional qualifications. Significant differences have been found in both factors: advantages of print editions, $\mathrm{F}(3,422)=3.10, \mathrm{p}<.01$ and advantages of electronic editions, $\mathrm{F}(3,422)=2.71, \mathrm{p}<.05$. Also, results have shown that with the increase of the professional qualifications, agreement to the advantages of electronic editions also increases, while agreeing with the advantages of the print editions decreases. This means that the level of agreement with the advantages of print editions and advantages of electronic editions differs significantly depending on which professional qualifications category the respondents belong to.

Finally, single-factor analyses of variance were used for comparison of differences between the singled out factors, depending on the four categories of the respondents' age. Significant differences have been found in both factors: advantages of print editions, $\mathrm{F}(3,413)=3.21, \mathrm{p}<.05$ and advantages of electronic editions, $\mathrm{F}(3,413)=2.71, \mathrm{p}<.05$. Also, analyses have shown that with the increase of the length of service, the agreement with the advantages of print editions increases, while agreement with the advantages of electronic editions decreases. The obtained results have shown that the level of agreement for both singled out factors differs significantly depending on the age category which the respondents belong to, which certainly was the expected finding.

\section{CONCLUSION}

The first two research hypotheses, regarding the age as opposed to the level of preference of print or electron- ic media, were confirmed in full and can be observed in correlation. Employees with longer length of service are older and therefore it is completely expected that they prefer print editions more, while employees with shorter length of service are younger and more frequently choose electronic editions of newspapers and magazines, because they are more open to the use of new technologies and new(er) media formats. This is confirmed by several foreign researches, including the ones of the Online Publishers Association (OPA) conducted last decade in its "Generational Media Study today" study, which focused on the category of users aged 18 to 34 . Majority of the respondents- $83 \%$ sad that reading a story on the Internet is the same or better than reading one in a newspaper.

As opposed to this, the hypothesis assuming that preference towards electronic editions increases with the reduction of financial abilities was not confirmed, since the level of agreement of the respondents with the advantages of electronic editions differs significantly depending on which of the four income level categories the respondent belongs to. The preference towards the electronic editions increases with the increase of income. This supports the obtained result, according to which the unemployed have significantly higher level of agreement with the advantages of the print media as opposed to the electronic ones. On the other hand, the level of agreement with the advantage of electronic editions factor increases with the increase of personal income.

The following hypothesis was confirmed, as it shows that the level of agreement with the advantages of print editions and advantages of electronic editions differs significantly depending on which category of professional qualifications the respondents belong to. This finding was expected, considering the fact that it is known that the level of education certainly impact the computer literacy.

The last and third hypothesis, which does not assume significant differences in preference towards print or electronic media, in terms of gender distribution, was not confirmed. Obtained result shows significant in preference towards print or electronic media, in terms of gender distribution, which can be construed through traditionally higher preference of men towards the use of technics and technology.

Our conclusion regarding the research and results is that the media must follow the requirements of the market. This means that the media must change with the changing habits of people. In the past, the media sphere was under the control of media companies, but today is controlled by consumers. The media market 
is no longer triggered by the law of supply; it is triggered by the law of demands. One thing is certain: newspaper circulation will continue to decline, given the increasing availability of the Internet and fixed line and the number of technical devices that we carry when we are on the move (smartphones, PDA, etc.).

Newspapers should try to use journalistic capacity they have to create a separate medium on form of online portal that will be constantly updated, and will again be supporting some of the stories that they publish in printed editions. At the same time the newspapers should try to reduce the number of parties and be more informative, creating quality portal, which will be charged to the latest information, new photographs andvideos, but without neglecting the classical standards and functions of journalism. The new media environment allows easier following of the audience and its preferences, based on the number of article, the number and content of comments, etc. This information is an important indicator for editors and journalists considering what topics (and in what direction) should be further investigated, both for print an on-line editions.

\section{References:}

1. Bartlett, D. (1994). The soul of a news machine: Electronic journalism in the twenty-first century. Federal Communications Law Journal, Vol. 47(3), pp. $1-23$.

2. Boczkowski, P. (2004). The process of adopting multimedia and interactivity in three online newsrooms. Journal of Communication. Vol. 54, No. 2, p. 197-213.

3. Bressers, B. (2006). Promise and reality: The integration of print and online versions of major metropolitan newspapers. The International Journal on Media Management, Vol. 8(3), pp. 134-145.

4. Cappo, J. (2004). Budućnost oglašavanja. Sarajevo: Futura Media.

5. Chan-Olmsted, S., Ha, L. (2003). Internet business models for broadcasters: How television stations perceive and integrate the Internet. Journal of Broadcasting \& Electronic Media, Vol. 47(4), pp. 597617.

6. Chyi, H., Lewis, S. (2009). Use of online newspaper sites lags behind print editions. Newspaper Research Journal, Vol. 30(4), pp. 38-53.

7. Ketterer, S. Weir, T., Smethers, J. S., Back, J. (2004). Case study shows limited benefits of convergence. Newspaper Research Journal, Vol. 25(3), pp. 52-65.

8. OPA Generational Media Study Yields Interesting Results, http://digital-lifestyles.info/2004/09/24/opagenerational-media-study-yields-interesting-results/ (Accessed 07.07.2016.).

9. Perić, N., Krasulja, N, Radojević, I. (2011). Medijske, PR i brend tendencije, drugo, dopunjeno izdanje. Beograd: Synopsis.

10. Picard, R. G. (2000). Changing business models of online content services: Their implications for multimedia and other content producers. Journal of Media management, 2 (11), 60-68.
11. Picard, R. (2006). Journalism, Value Creation, and the Future of News Organisations. Working Paper 2006-4, Cambridge, MA: Joian Shorenstein Center for the Press, Politics and Public Policy, John F. Kennedy School of Government, Harvard University.

12. Picard, R. (2010). The future of the news industry. The Future of the News Industry in James Curran, (ed.) Media and Society. London: Bloomsbury Academic.

13. Rogers, E. (1995). Diffusion of innovations. New York: Free Press.

14. Saksena, S., Hollifield, C. (2002). U.S. Newspapers and the development of online editions. The International Journal on Media Management, Vol. 4(2), pp. 75-84.

15. Schrøder, K. (2011). Audiences are inherently cross-media: Audience studies and the cross-media challenge. Communication Management Quarterly: Časopis za upravljanje komuniciranjem. Vol. 18, Spring, pp. 5-28.

16. Seelig, M. (2007). A cross-media response to the web as an outlet of information: A comparison of news websites. International Journal of Technology, Knowledge \& Society. Vol. 3(3,) pp. 117-130.

17. Seelig, M. (2008). An updated look at trends in content and web page design in news websites: A content analysis of newspapers, radio stations and television stations websites. Electronic News. Vol. 2(2), pp. 86-101.

18. Seelig, M. (2011). Web Economics: The Added Value of the Web for Daily Newspapers and Commercial Television Stations. Journal of Multidisciplinary Research, Vol. 3(1), pp. 81-96.

19. Veglis, A. (2007). Cross-media publishing by U.S. newspapers, Journal of Electronic Publishing. The Journal of Electronic Publishing. Vol. 10(2), http:// hdl.handle.net/2027/spo.3336451.0010.211, (Accessed 10.04.2017.). 


\section{Apstrakt:}

\section{Percepcija javnosti o štampanim i elektronskim izdanjima novina i časopisa u Srbiji}

Nenad Perić, Milica Vasiljević Blagojević, Nenad Vujić

Kako u Srbiji još uvek nema kompleksnih istraživanja na temu stanja štampanih i elektronskih medija u smislu odnosa preferencija prema njima, ovaj rad ima za cilj da pruži inicijalne smernice u tom pogledu. Koristeći u svrhe ovog istraživanja formulisan anketni list, ispitanici su na skali procene iznosili stavove o prednostima i manama štampanih odnosno elektronskih medija. Istraživanje je sprovedeno na nivou Srbije, sa velikim brojem ispitanika (432). Korišćeno je više različitih varijabli na skali Likertovog tipa. Ispitanici su procenjivali ukupno deset tvrdnji koje su se odnosile na različite aspekte prednosti i mana štampanih i elektronskih izdanja. Rezultati do kojih smo došli mogu biti od velikog značaja kako za same medije tako i za ostale učesnike u oglasnoj industriji-oglasne agencije i oglašivače. Naučni doprinos ovog rada ogleda se u inicijalnim podacima koje su istraživači dobili u oblasti medija, marketinga i oglašavanja, a u vezi sa percepcijom štampanih i elektronskih izdanja u RS.

Ključne reči: novine, elektronska izdanja, novinarstvo, informacije, potrošači

\section{Kontakt:}

Nenad Perić, vanredni profesor Fakulet za menadžment Univerzitet Metropolitan Beograd Tadeuša Košćuška 63, Beograd nesaperic@yahoo.com

Milica Vasiljević Blagojević, profesor strukovnih studija Visoka zdravstvena škola strukovnih studija Beograd

Cara Dušana 254, Beograd milica@tojo.rs

Nenad Vujić, viši naučni saradnik Ekonomski institut Beograd Kralja Milana 6, Beograd nenadvujicvuja@open.telekom.rs 